\title{
Güç Alanı Kuramı Bağlamında Destekleyici/Güdüleyici ve Engelleyici Algıların Girişimcilik Niyetine Etkisi
}

\section{The Effect of Motive and Barrier Perceptions on the Entrepreneurial Intention in the Context of Power Field Theory}

\author{
Zeki UÇAR, Türkiye, zeki.ucr@gmail.com \\ Orcid No: 0000-0001-7491-5703 \\ Oytun Boran SEZGIN, Dokuz Eylül Üniversitesi, Türkiye, boran.sezgin@deu.edu.tr \\ Orcid No: 0000-0002-6671-8053
}

\begin{abstract}
Öz: Bu çalışmanın amacı bireylerin girişimciliğe yönelik destekleyici ve engelleyici algılarını güç alanı kuramı kapsamında ele alarak, bu algıların kümülatif gücünün girişimcilik niyeti üzerindeki etkilerini değerlendirmektir. Nicel olarak tasarlanan çalışmada, alan araştırması yöntemi ve yazılı soru sorma tekniğinden faydalanılmıştır. Veriler, Bitlis Eren Üniversitesi ve Dokuz Eylül Üniversitesi İktisadi ve İdari Bilimler Fakültelerinde lisans düzeyinde öğrenim gören 494 öğrenciden toplanmuştır. Çalışmada, güvenilirlik, açımlayıcı faktör, korelasyon, regresyon ve t-testi analizleri gerçekleștirilmiştir. Analizler sonucunda, özendirici faktörler özgerçekleştirme, saygınlık ve işten bekleniler olmak üzere 3 boyutlu olarak tespit edilmişstir. Engelleyici faktörler ise yetkinlik eksikliği, destek eksikliği, kurulum kaygıları ve uygulama kayglları olarak 4 boyutlu belirlenmiştir. Destekleyici algıların tüm boyutları, girişimcilik niyetini anlaml ve poitif yönde etkilerken, engelleyici algıların tamamı girişimcilik niyetini anlaml ve negatif yönde etkilemektedir. Gü̈ç analizi teorisi bağlamında; destekleyici algılar girișimciliğe çeken güçler, engelleyici algılar ise girișimciliği iten güçler olarak değerlendirilmiştir. Analitik hiyerarş̧i sürecinden faydalanılarak söz konusu boyutlar girişimcilik konusunda uzman 8 kişi ile değerlendirilmiş ve boyutlar ağırlıklandırılmıştır. Destekleyici ve engelleyici etmen puanları belirlenmiş ve söz konusu puanların fark (destekleyici etmen-engelleyici etmen) pozitif ve negatif olmasına göre örneklem sinıflandırılmıştır. Farkın pozitif olduğu grup ile farkin negatif olduğu grup arasında girişimcilik niyeti ortalamaları arasında anlamlı bir fark olduğu bulgulanmıştır. Araşstırmada nihai olarak destekleyici/güdüleyici güçler ve engelleyici güçler arasındaki orantısızlık kissi karar ve davranıssın bu iki farklı gücün pozitif farkı yününde olumlu yada olumsuz olarak etkileyeceği sonucuna ulaşılmıştır. Bu fark destekleyici/güdüleyiciler yönünde pozitif olarak arttıkça giriş̧imcilik niyeti de yükselmektedir.
\end{abstract}

Anahtar Sözcükler: Güç Alanı Teorisi,, Girişimcilik Niyeti, Destekleyici Algılar, Engelleyici Algılar

Abstract: The aim of this study is to examine the motive and barrier perceptions of individuals within the scope of the field of power theory and to evaluate the effects of cumulative force of these perceptions on entrepreneurial intention. Quntitative approach is adopted. Field research method and survey form is used in the study. Data are collected from 494 students at Bitlis Eren University and Dokuz Eylül University. In the study, reliability, exploratory factor, correlation, regression and t-test analyzes are performed. As a result of the analyzes, the motive factors are determined in three dimensions as self-realization, respectability and expectations from work. Barrier factors are identified as lack of competence, lack of support, start-up concerns and application concerns. While all dimensions of motive perceptions affect entrepreneurial intention in a meaningful and positive direction, all barrier perceptions affect entrepreneurial intention in a meaningful and negative way. In the context of power analysis theory; motive perceptions are considered as the forces that attracted entrepreneurship and barrier perceptions are the ones that pushed entrepreneurship. Using the analytic hierarchy process, all dimensions are evaluated with 8 experts in entrepreneurship and the dimensions are weighted. Encouraging and inhibiting factor scores are determined and the sample is classified according to the difference between the scores (positive and negative). There is a significant difference between the mean of entrepreneurial intention between the group with positive difference and the group with negative difference. Furthermore, as the difference increases positively, the entrepreneurial intention increases.

Keywords: Force Field Theory, Entrepreneurial Intention, Perceptions of Motives, Perceptions of Barriers

\section{Giriş}

Girişimciliği geliştirmek ekonomik ve sosyal mübadeleler içindeki günümüz toplumlarının başarısı için artık kritik bir önem kazanmıştır (Obschonka vd., 2010: 63). Bir ülkedeki girişimcilik faaliyetleri arttıkça, ülkenin ekonomik büyümesi de hızlanmaktadır (Wennekers ve Thurik, 1999). Dolayısıyla, girişimcilik ve girişimcilik süreci ile ilgili araştırmacıların merakı artmaktadır (Kuratko vd., 1997). ByGrave (1993) tarafindan "firsatları kovalamak için yeni bir örgüt yaratılması" olarak tanımlanan girişimcilik olgusu, girişimci niyeti daha yüksek olan bireyler tarafindan gerçekleştirilmesi beklenmektedir (Bae vd., 2014). Çünkü girişimcilik davranışı, niyetli olarak ortaya çıkan planlı bir davranıştır (Krueger vd., 2000). Nitekim niyet, davranışa en yakın öncüldür ve belirli bir davranış ile ilişkilendirilen bilişsel, motivasyonel ve etkili iç süreçlerin belirli bir kesitte buluşmasını kapsar. Davranışa yönelik niyet, belirli güçlerin etkisi altında, davranışa yönelik tutumlar, sübjektif normlar ve davranış üzerinde algılanan kontrolün bir fonksiyonu olarak ele alınmaktadır (Erten, 2002: 220).

Gerçekleştirilen araştırmalar, niyet-davranış araştırmalarında olduğu gibi girişimcimsel faaliyetleri de sadece tutumlarla ya da dış kaynaklı etmenlerle açıklamanın zayıf bir öngörü koyduğunu göstermektedir (Krueger vd., 2000: 414). Bird'e göre (1988: 443) bir işletmenin kuruluşunda, kurucunun (girişimcinin) niyetinin etkisi çok önemlidir.

Makale Gecmiși / Article History

Başvuru Tarihi / Date of Application Kabul Tarihi / Acceptance Date 
İşletme kuruluşu için gereksinim duyulan bilginin araştırılması bile, girişimsel faaliyet için niyetin göstergesi olabilir (Katz ve Gardner, 1988: 434-435). Krueger ve Carsrud (1993), girişimciliği planlı davranış kuramı ile değerlendirerek; niyetin girişimsel davranışın en önemli öncülü olduğunu ve girişimsel davranışın çekiciliği, girişimsel davranışın algılanan sosyal normları ve girişimsel davranış için algılanan öz yeterliliğin niyetin oluşmasındaki üç temel unsur olduğunu iddia etmektedirler. Krueger ve diğerlerine göre (2000) girişimciliğin de dahil olduğu herhangi bir planlı davranış için tek olan en iyi öncül niyettir. Girişimsel niyet ya da girişimcilik niyeti olarak ifade edilen bu kavram bireyin yeni bir işletme kurmak için niyetli olmasını ifade etmektedir (Engle vd., 2010: 38).

Görgül araştırmalar (Kolvereid, 1996a; Tkachev ve Kolvereid, 1999; Engel vd., 2010) da niyet temelli süreç ve girişimcilik davranışı arasındaki ilişkiyi ortaya koymaktadır. Engle ve diğerleri (2010) 12 ülkedeki öğrenciler üzerinde gerçekleştirdiği araştırma ile Ajzen'in planlı davranış teorisi gibi bilişsel teorilerin bağlamında girişimcilik araştırmalarına katkıda bulunacağını iddia etmektedirler. Kolvereid (1996b) Norveç'teki 128 işletme öğrencinin istihdam tercihleri niyetlerinde Ajzen'in planlı davranış teorisi boyutlarının etkilerini bulgulamıştır. Benzer şekilde Tkachev ve Kolvereid, 512 Rus öğrenci üzerinde girişimcilik niyetinin planlı davranış teorisi ile inceledikleri çalışmada, demografik değişkenlerin değil tutum, sübjektif norm ve algılanan davranışsal kontrolün girişimcilik niyetini belirlediğini tespit etmişlerdir.

Girişimcili niyeti modelleri gün geçtikçe araştırmacıların dikkatini daha fazla çekmektedir (Fayolle ve Linan, 2013; Lortie ve Castogiovanni, 2015). Çünkü insanların zihnindeki mental prototipler ve bilişsel senaryolar ile girişimsel karar alma sürecini anlamak girişimcilik niyeti araştırmalarıyla olanaklı hale gelecektir (Fayolle ve Linan, 2013). Bu aşamada ise girişimcilik niyetini etkileyen güçlerin/öncüllerinin incelenmesi önem kazanmaktadır.Pruett vd.'ne göre (2009) girişimcilik niyetini etkileyen önemli değişkenlerden ikisi bireylerin girişimcilik ile ilgili algıladıkları destekleyiciler/güdüleyiciler ve engellerdir. Girişimciliğin görece yüksek fayda, ödül, firsat, bağımsızlık, yaratıcılık gibi olumlu sonuçlar sunduğuna daha fazla inanan bireylerin girişimcilik niyetleri artmaktadır. Benzer şekilde, bilgi ve sermaye eksikliği, girişim kurma ve girişimi sürdürme kaygıları ise girişimcilik niyetini azaltmaktadır (Pruett vd., 2009). Fakat bu ilişkiler Lewin'in Alanı Kuramı (1997) bağlamında değerlendirildiğinde; bireyin etrafındaki yaşam alanının kendi üzerinde oluşturduğu destekleyici/güdüleyici ve engelleyici güçlerin kümülatif etkisine göre birey davranışları şekillenecektir (Sundberg vd., 2002; Schultz ve Schultz 2001; Berthaume vd., 2014). Dolayısıyla bu iki faktörün etkileşiminin sonucunda ortaya çıkan güç, bireylerin girişimsel faaliyetlerini şekillendirecektir. Kısacası, planlı davranış kuramı ile açıklanan girişimcilik niyetini etkileyen en önemli etmen bireyin girişimciliğe yönelik güdüleyici ve engelleyici algılarının etkileşiminin oluşturduğu güçtür. Bu bağlamda, bireylerin girişimcilik niyetlerine etki eden destekleyici/güdüleyici faktörlere ilişkin algıları, engelleyici faktörlere ilişkin algılarından daha yüksek olduğunda girişimcilik niyetlerinin çok daha yüksek olacağı düşünülmektedir.

Çalışmanın amacı, girişimciliğe yönelik destekleyici/güdüleyici ve engelleyici faktörlerin 'güç alanı teorisi' bağlamında değerlendirilerek, bu algıların kümülatif gücünün girişimcilik niyetine etkisi belirlemektir. Özellikle, güç alanı kuramı perspektifinden yapılan bu değerlendirmenin, araştırmacılara çalışmalarında ele almış oldukları temel değişkenlerini (bağımlı değişkeni) etkileyen olumlu ve olumsuz tüm faktörleri birlikte değerlendirme yönünden farklı bir bakış açısı sunarak katkı sağlayacağı umulmaktadır. Diğer yandan girişimcilik alanındaki eğitmenlerin ve politika yapıcıların, girişimcilik eğitiminin içeriğinde bireylerin girişimci davranışlarının önemli bir öncülü olarak değerlendirilen girişimcilik niyetinin geliştirilmesinde sadece girişimciliğe yönelik güdüleyici algılarının artırılmasına yönelik faaliyetlerin değil, yüksek engelleyici algılarının düşürülmesine yönelik faaliyetlere de dikkatini çekerek konuya ilişkin farkındalığın artırılması hedeflenmektedir.

\section{Kavramsal Çerçeve}

\subsection{Girișimcilik Niyeti}

Ajzen (1991) niyeti bir kişinin; motivasyonu, çaba göstermeye istekliliği ve belli zorlukların üstesinden gelmek için gönüllü olması bileşenlerinin etkileşimi olarak tanımlamakla birlikte, niyetin davranışın en önemli belirleyicisi olduğunu ve niyetin; davranışa yönelik tutum, sübjektif norm ve algılanan davranışsal kontrolden oluşan 3 boyutlu temeli olduğunu belirtmektedir. Tutum, belirli bir davranışı sergileyecek kişinin o davranışın gerçekleşmesi yönünde pozitif veya negatif değerlendirmeleri olarak belirli bir davranışı ortaya koymanın sonuçları hakkındaki inançları ifade etmektedir. Subjektif norm, kişi ve kurumların davranışın ortaya konup konmaması yönünde ne tür bir beklenti içinde oldukları hakkında bireyin algısıdır (Erten, 2002: 221). Kontrol ise kişinin davranışa yönelik olarak kendi kapasite veya yetenek ve şansı hakkındaki öz değerlendirmelerini ifade etmektedir (Casper, 2007: 1324). Buna göre niyet, belirli bir davranışı gerçekleştirmek için bireyin zoru denemeye ne kadar gönüllü olduğunu ve planladıklarını ne derece uygulayacağının göstergesi olarak ne kadar güçlü ise kişinin performans düzeyinin de o denli artacağı var sayılmaktadır (Ajzen, 1991: 181). Ayrıca bireylerin belirli bir faaliyeti gerçekleştirme konusunda kişisel ve sosyal beğenilirliği ve söz konusu faaliyeti gerçekleştirmek için gerekli yetenek ve becerilere sahip olduğu inancı arttıkça, bireylerin söz konusu faaliyeti gerçekleşmesi olasılı̆̆ı yükselmektedir (Engle vd., 2010: 37).

Niyet temelli süreç modellerinde, yetenek, bilgi ve beceri gibi davranışı etkileyen dış kaynaklı etkenlerin hedef davranışa dolaylı etkisi varken, niyet doğrudan davranışı etkilemektedir (Krueger ve Carsrud, 1993: 316-317). Bu bağlamda ilgili yazın incelendiğinde iki kritik konunun genel olarak kabul edildiği gözlenmektedir. Birincisi, niyetin karar vericinin dikkatini hedef davranışa yönelttiğini, dolayısıyla davranışın en önemli göstergesi/belirleyicisi 
olduğudur (Krueger ve Brazeal, 1994: 93). İkinci konu ise, niyeti etkileyen tutumların ve niyetin kendisinin alg1 temelli olduğu yani öğrenilebildiğidir (Krueger ve Brazeal, 1994: 93).

\subsection{Güç Alanı Kuramı}

Gestaltçı psikolog Kurt Lewin tarafından geliştirilen Alan Kuramı (Berthaume vd., 2014) birey ile toplam alan veya çevre arasındaki etkileşim kalıplarını incelemek için kullanılan (Lewin, 1997) bir sosyal davranış kuramıdır (Berthaume vd., 2014). Felsefe ve bilimsel yöntemleri birleştiren ve karmaşık bir yapıya sahip olan alan kuramı, matematik, fizik ve kimya gibi farklı disiplinlerden yararlanarak yeni bir sentez yapmıştır (Öner ve Eren Gümüş, 2000: 9). Kuram aslen sosyal durumlarda kullanılmak üzere geliştirilmiştir, ancak sosyal bilimler, psikoloji, sosyal psikoloji, örgütsel gelişim, süreç yönetimi ve değişim yönetimi alanlarına önemli katkılarda bulunmuştur (Lewin, 1997).

Alan Kuramı belirli bir duruma ilişkin ilk olarak bireyi etkileyen sosyal faktörleri belirlemek için bir çerçeve sunmaktadır. Bunu, çevrenin birey üzerindeki etkilerini nedensel ilişkilere dayalı analizlerle yaparken, bilimsel yapıların oluşturulmasına da yardımcı olmaktadır (Lewin, 1997) . Sharf (2000), Alan kuramının alanı bireyin etkileşim içerisinde olduğu çevre olarak tanımlarken, bu çevrede tüm parçaların sistematik bir bütünlük oluşturduğunu belirtmektedir. Dolayısıyla alan kuramı olayları değerlendirirken bireye etki eden tüm alanı dikkate almaktadır (Kirchner, 2000). Nitekim her birey kendi etrafında varlığını sürdürdüğü olan bir yaşam alanına sahiptir. Bireyin tüm faaliyetlerini yapılandırdı ğı yaşam alanı bireyin davranışlarını etkilemektedir. Dolayısıyla yaşam alanındaki herhangi bir değişiklik kişinin dinamik olan yaşam alanını yeniden yapılandırır. Bu şekilde davranışa neden olan uyarıcılar da değişir (Schultz ve Schultz 2001). Bu uyarıcılar, bireyin uyarıcıların varlığını nasıl içselleştirdiğine bağlı olarak, kendisiyle ilişkili farklı kuvvetler dizisine sahiptir. Ortaya çıkan bu kuvvetler aracıyı yönetir ve bir yanıtı (veya bir cevap eksikliğini) dikte eder. Güçler çeken veya iten kaliteye sahip olabilir ve her yaşam alanında birden fazla güç olabilir. Bu güçlerin kümülatif etkisi, bireyin/öznenin nasıl hareket edeceğini, davranacağını, etkileşeceğini ve yapacağı seçimleri belirler (Berthaume vd., 2014). Dolayısıyla alan teorisi iki tür kuvveti hesaba katar: hareketi bir hedefe doğru sürükleyenler (destekleyici kuvvetler) veya bir hedefe doğru hareketi engelleyenlerdir (engelleyici kuvvetler). Bu kuvvetler, birey tarafından deneyimlenen diş uyaranlarla meydana gelir. Alan teorisi, bireyin dış uyaranları nasıl içselleştirdiğine bağlı olarak, bireyin yaşam alanındaki değişiklikleri gösterir. Bu nedenle, alanın herhangi bir kısmının durumu, diğer kısımlarıyla da bağlantılıdır (Sundberg vd., 2002).

\subsection{Yeni Girişim Kararına Etki Eden Destekleyici ve Engelleyici Faktörler}

Günümüzdeki ekonomik koşullar, öngörülemeyen işten çıkarmalar, küçülme ve kariyer büyümesi için fırsat eksikliği nedeniyle bazı bireyleri, iş arama konusunda kendi işlerini kurmaya zorlamaktadır (Hughes, 2003). Bununla birlikte kendi işine sahip olma fırsatı, geleneksel istihdama alternatif olmaktadır. Bu nedenle işsizlerin karar alma sürecine etkili olan güçleri anlamak önemlidir. Günümüzde, işgücü piyasasına geçiş yapan birçok kişi, kendi işini kurmayı, ekonomik olarak kendi kendine yeterlilik için uygun bir seçenek olarak görmektedir. Bununla birlikte bireyin işe başlama kararı, karmaşık ve çok yönlü bir süreçtir. Her ne kadar bireyin girişimci olmaya karar vermesinin temel nedeni olarak ekonomik nedenler gösterilse de (Baker \& Pollock,2007: 301), çoğu girişimci için başarının anlamını tek başına ekonomik nedenler değildir ve bu nedenler oldukça çeşitlilik göstermektedir (Franklin, 2013: 27-28). Preut vd., (2009) destek ve engellere yönelik algıların dikkate alınmasını belirtirken, bireyin yeni bir girişimi başlatıp başlatama doğrultusundaki niyet ve kararının destekleyici ve engelleyici algılardan etkilendiğini savunmaktadırlar. Bireyin inancının gücü, bu inanca duyduğu güven ve mevcut kanıtlar üzerine hareket etme niyeti, girişimcilik niyetini etkiler. Çünkü niyetler, girişimciliğin görece benzersiz yararlar, ödüller veya firsatlar sunduğuna olan inancin gücünden olumlu yönde etkilenmekte ya da bilgi ve başlangıç sermayesi eksikliği veya işletme riskleri gibi girişi zorlaştıran başlangıç engellerinden olumsuz olarak etkilenmektedir (Pruett vd., 577).

Girişimci adaylarının yeni iş kurma kararı almalarında destekleyici/güdüleyici faktörlere ilişkin algıları önemli hale gelmektedir (Zimmerer ve Scarborough, 2005: 6). Yazın incelendiğinde girişimcilik destekleyici/güdüleyicilerine ilişkin birçok araştırma makalesinin olduğu görülmektedir. Bu çalışmaların sonuçları derlendiğinde girişimcilik destekleyici/güdüleyicilerine ilişkin birçok değişken ön plana çıkmaktadır. Bunlar: daha fazla para kazanma arzusu, içsel kontrol odağına sahip olmak, özerk ve bağımsız davranabilme ihtiyacı, bilgi ve deneyimini kullanma arzusu, serbest meslek sahibi olmak, pazarda ihtiyaç hissetmek, iş alanına duyulan ilgi, sermaye sahibi olmak, girişimcilik eğitimi almış olmak, organizasyon becerilerine sahip olmak, geniş bir çevreye sahip olmak, üretimle ilgili teknik bir bilgiye sahip olmak, mevcut işteki hayal kırıklığı, rol modelini takip etme, onaylanma ihtiyacı, arzulanan iş tatmini, kişisel gelişim ihtiyacı, girişimciliği refah ve zenginlik aracı olarak algılama, toplum refahına katkıda bulunmak, girişimciliğe aile desteğinin olması, piyasa değeri, kendiyle gurur duyma, eğlenceli olduğu yönündeki algı, yardım severlik, vergi indirimi, örgütsel dinamikler, piyasaların uluslararasılaşması ve dev firmaların yeniden yapılanmaları, destekleyici ulusal kültür ve destekleyici çevre, medyanın etkisi, örgüt içi ilerleme yönündeki engeller, iş ihtiyacı /işsizlik sorunları, ailevi kaygılar, finansal başarı, kendini ispatlama, risk alma düzeyi, belirsizliğe karşı tolerans, tanınma/statü/prestij, kariyer esnekliği olması, aile politikaları, aile yükümlülükleri, ilerleme, servet yapma/çok para kazanma, iyi bir iş fikrinin olması, ilginç bir işe sahip olmak, işyerinde ayrımcılıktan kaçınma, patrondan veya kısıtlamalardan kaçınma, kendi kendine yeten ve kendi kendine uyumlu bir şekilde hareket etmek, kendi işinin patronu olmak, özel sektörde çalışmanın getirdiği stresten uzak durma, sorumlu olma düşüncesi, kendi hayatını kontrol edebilme, kendi işinden emekli olma, beceri ve yeteneklerini kullanabilme, başarı güdüsü, roller, iş tatmini, özgüven, 
firsatları değerlendirme, toplum içerisinde saygınlık kazanma, ekonomik ihtiyaç, güvenlik ihtiyacı, vizyon sahibi olma, istikrar, güç sağlama, yaşam tarzı, liderlik özelliklerinin oluşu, yenilikçilik, ekonomik koşullar, işten çıkarılma, firmaların küçülmesi, kariyer yükseltmek için fırsat eksikliği, hayallerini gerçekleştirme, ego, mücadele, teknolojideki gelişim, teknolojinin yaygınlaşması, kişisel kazanç sağlama, kamu destekleri, kariyer zenginleştirme, iş alanları yaratma, beceri geliştirme, yetki, tüm süreçlere katılım ( Hisrich ve Brush, 1986; Birley ve Westhead, 1994; Kaufmann, 1995; Gatewood vd., 1995; Kolvereid, 1996a; Koh, 1996; Ageev Buttner ve Moore, 1997; Feldman ve Bolino, 2000; Lee ve Peterson, 2000: Srivastava vd., 2001; Amit vd., 2001; Dauglas ve Shepherd, 2002; Shane vd., 2003; Hughes, 2003; Carter vd., 2003; Lüthje and Franke, 2003; DeMartino ve Barbato, 2003; Wilson vd., 2004; Zimmerer ve Scarborough, 2005; Apospori vd., 2005; Van Gelderen ve Jansen, 2006; Choo ve Wong, 2006; Edelman vd., 2010; Heyter, 2011, Korkmaz, 2012; Gözek ve Akbay, 2012; Kunday, 2014; Akpınar ve Küçükgöksel, 2015) olarak belirtilebilir.

Yukarıda belirtilmiş olduğu gibi yeni bir iş kurma kararını olumlu etkileyen bir çok faktör olmasının yanı sıra iş kurma kararını olumsuz olarak etkileyen nedenlerde bulunmaktadır (Wickham, 2006: 103). Ancak yazın incelendiğinde araştırmaların daha çok destekler/güdüleyiciler üzerinde yoğunlaştığı görülürken; bireylerin işsizlikten yeni bir girişim yaratmaya geçişte önündeki engellerin değerlendirilmesine oldukça az ilgi gösterilmiştir (Hatala, 2005: 51; Marangoz ve Aydın, 2018: 71). Oysa Hatala'nın (2005: 50) da belirttiği gibi bireyin yeni girişim yaratma kapasitesini oluşuz yönde etkileyecek faktörlerin bilinmesi, bireyin kendi kendine yetme aracı olarak yeni bir iş kurma olasılığını arttıracaktır. Nitekim günümüz çalkantılı/değişken ekonomilerinde bireyin kendi kendine yeterliliğe geçişini güçlendirmek için yeni firsatlar aramaya duyulan ihtiyaç en önemli öncelik haline gelmiştir. Ekonomik belirsizlik çağında geleneksel istihdama alternatif sağlamak, işsiz kalan insanlar için önemlidir. Bu bakımdan iş geliştirmenin önündeki engellerin belirlenerek, bunların üstesinden gelmek için özel müdahalelerde bulunmak, çok sayıda insan için yeni girişim kararını hızlandırabilir. (Hatala, 2005: 69). Martins (2004) endüstri, bölge ve işletme türlerine bağlı olarak girişimciliğin önündeki engelleri üç kategoride sınıflandırmaktadır. Bunlar 1) Düzenleyici engeller (Giriş engelleri gibi), 2) Kültürel ve sosyal engeller (Başarısızlık korkusu ve girişimciliğe ilişkin bilgi ve beceri eksikliği gibi) 3) Finansal ve ekonomik engellerdir (Risk sermayesine erişememe, kısa ve uzun dönem finansman eksikliği gibi) (Martins 2004'den aktaran, Marangoz ve Aydın, 2018: 71). İlgili yazın incelendiğinde girişimciliğin önündeki engellerin, özgüven eksikliği, cesaret eksikliği/riskten kaçınma, başarısızlık korkusu, sosyal ağ eksikliği, kaynak eksikliği, stres ve ağır çalışma koşullarından kaçınma, işten çıkarılma, kötü ekonomik görünüm ve ekonomik belirsizlik, yasal yükümlülükler/vergi yükü, iş kurmanın maliyetli oluşu, başlangıç sermayesi yetersizliği, reklam giderleri, lisanslama süreç ve gereklilikleri, kamu desteği bulamama, sermaye yetersizliği ve sermaye temin etmekte karşılaş1lan güçlükler, kuruluş için gerekli olan sermaye maliyetlerinin yüksek olması, endüstri çevresinin barındırdığı riskler, yasal engeller, yeni iş kurma sürecine ilişkin bilgisizlik, beceri eksikliği, girişimcilik eğitimi alınmamış olmaș/girişimcilik bilgi eksikliği, girişimcilik imajına yönelik yanlış alg1, işgücünde karşılaş1lan sorunlar ve işgücü yetersizliği, kişisel özelliklerin girişimcilik eğilimini olumsuz etkilemesi, başlangıç desteği eksikliği, ailesel sorunlar/aile rızasının olmaması, zaman kısıtı, beceri eksikliği/tecrübesizlik, bürokratik engeller, gelir güvencesinin olmaması, uzun saatler çalışmayı gerektirmesi, bilgi eksikliği, bankaların yeni projeleri finanse etme konusundaki isteksizliği, arkadaş ve ailenin olumsuz tutumları, başarısızlıkla ilişkilendirilen utanç, iyi bir iş fikrine sahip olmamak, (David ve June, 2001; Hughes, 2003; Hatala, 2005; Lee vd., 2005; Choo ve Wong, 2006; Wickham, 2006; Li, 2007; Shinnar vd., 2009; Gözek ve Akbay, Fatoki ve Chindoga, 2012; Gözek ve Akbay, 2012, Singh Sandhu vd., 2015; 2012; Kunday, 2014; Moon vd., 2014; Akpınar ve Küçükgöksel, 2015; Marangoz ve Emre, 2018) olduğu anlaşılmaktadır.

\section{Kuramsal Çerçeve}

Pruett vd. (2009: 577) girişimciliğe yönelik fayda, ödül veya firsatların sunduğu değerin gücünün yani destekleyici/güdüleyici etmenlerin girişimcilik niyetini olumlu etkilediğini ifade etmektedirler. Hem erkek hem de kadın için girişimciliğe yönelik önemli çekici faktörlerden dördü bağımsız çalışma arzusu, para kazanma, başarı duygusunu tatmin etme ve yaşam stilini değiştirme isteğidir (Kirkwood, 2009: 352; Humbert ve Drew, 2010: 178). İşteki mutsuzluklar hem erkeklerde hem de kadınlar da girişimciliğe yönelik eğilimlerini itici faktör olarak geliştirmektedir (Krikwood, 2009: 352; Humbert ve Drew, 2010: 178). Begley ve diğerleri (2011) girişimciliğin sosyal statüsünün, MBA öğrencileri için girişimciliği daha çekici kıldığını belirtmektedirler (Lüthje ve Frankie, 2003: 139).,Bu bilgiler doğrultusunda, güdüleyici algıların girişimcilik niyetini pozitif yönde etkileceği düşünülmektedir.

H1: Güdüleyici algılar, girişimcilik niyetini pozitif olarak etkilemektedir.

Pruett vd. (2009:577) bilgi eksikliği, başlangıç sermayesi veya uygulama kaygıları gibi engelleyici algıların girişimcilik niyetini olumsuz etkilediğini belirtmektedirler. Özellikle aile desteği, girişimcilik niyetini olumlu yönde desteklerken (Pruett vd., 2009: 576), söz konusu desteğin yokluğu ya da eksikliği de girişimcilik niyetini olumsuz etkilemektedir. Denanyoh vd. (2015: 25-27) yapısal destek olarak adlandırdığı finans ve kamu kurumlarının girişimciliğie yönelik desteklerinin girişimcilik niyetini artırdığını bulgulamışlardır. Benzer şekilde Lüthje ve Frankie (2003: 140), bireylerin çevresindeki belirgin yapısal etmenlerin negatif olması durumunda girişimcilik niyetinin azalacağını belirtmektedirler. Begley ve diğerleri (2005: 50) politik ve ekonomik koşulların sübjektif değerlendirmelere neden olduğuna ve devlet düzenlemelerinin girişimcilik niyeti ile ilişkisi bulunduğuna değinmektedirler. İsmail vd. (2009:56) yasal, iş planı, finans gibi konularda bilgi eksikliğinin girişimciliğe yönelik eğilimi azaltacağını iddia etmektedirler. Bu doğrultuda, engelleyici algıların girişimcilik niyeti üzerinde negatif bir etkisi olacağı beklenmektedir. 
H2: Engelleyici alg1lar, girişimcilik niyetini negatif olarak etkilemektedir.

Alan kuramı bağlamında, girişimcilik niyetini asıl olgu, güdüleyici algıların oluşturduğu güdüleyici etmen ile engelleyici algıların oluşturduğu engelleyici etmenin kümülatif gücüdür. Bu bağlamda, bireylerin girişimcilik ile ilgili güdüleyici algıları, engelleyici algılarından daha yüksek olduğunda girişimcilik niyetlerinin çok daha yüksek olacağı düşünülmektedir.

H3: Güdüleyici etmen ile engelleyici etmenin kümülatif gücüne ile girişimcilik niyeti düzeyi arasında anlamlı bir fark bulunmaktadır.

Tekrar alan kuramı bağlamında, kümülatif güç pozitif yönde arttıkça, bireyin davranışlarını düzenleyen gücün etkisinin artması nedeniyle girişimcilik niyeti de güçlenecektir. Bu doğrultuda:

H4: Güdüleyici etmen ile engelleyici etmenin kümülatif gücü, girişimcilik niyetini pozitif olarak etkilemektedir.

\section{Metodoloji}

Kantitatif olarak tasarlanan çalışmada faydalanılan yöntem alan analizi, veri toplama tekniği ise yazılı soru formudur. Kolayda veri toplama yöntemi ile Bitlis Eren Üniversitesi, İktisadi ve İdari Bilimler Fakültesi ve Mühendislik Fakültesi ve Dokuz Eylül Üniversitesi, İktisadi ve İdari Bilimler Fakültesi’ndeki toplam 516 öğrenciden veri toplanmıştır. Doldurulan formlardan 22 tanesi, eksik ya da yanlış veri içerdiğinden araştırma dişında bırakılmıştır. Veriler, 2019 Mart ayı ile 2019 Aralık ayları içinde toplanmıştır.

Çalışmada kullanılan soru formu, iki kısımdan oluşmaktadır. İlk kısımda girişimcilik ile ilgili destekleyici/güdüleyici ve engelleyici faktörlerlere ilişkin birey algılarını ve bireylerin girişimcilik niyetini ölçmeye yönelik ifadeler bulunmaktadır. Soru formunun ikinci kısmında ise katılımcıların demografik bilgilerini içeren 6 soru bulunmaktadır. Girişimcilik ile ilgili destekleyici/güdüleyici etmenlere ilişkin algıları (16 madde) ve engelleyici faktörleri ilişkin algıları ölçmek için (20 madde) Pruett vd.'nin (2009) çalışmasından, girişimcilik niyeti ölçeği (6 madde) içinse Linan ve Chen (2009) çalışmasından faydalanılmıştır. Ölçek maddeleri Türkçe'ye çevrilmiştir. Çevrilen maddeler iki (2) uzman tarafından kontrol edilmiştir. Tüm ifadelerin dahil olduğu soru formu 5'li Likert ölçekleme yönteminden (1=Kesinlikle Katılmiyorum, 2=Katılmıyorum, 3=Ne Katılıyorum Ne Katılmiyorum, 4= Katılıyorum, 5=Kesinlikle Katılıyorum) faydalanılarak oluşturulmuştur.

Katılımcıların demografik bilgileri incelendiğinde, katılımcıların 139'u Bitlis Eren Üniversitesi, İktisadi İdari Bilimler Fakültesi'nde; 156 katılımcı Bitlis Eren Üniversitesi, Mühendislik Fakültesinde ve 189 tanesi de Dokuz Eylül Üniversitesi, İktisadi İdari Bilimler'de öğrenim görmektedir. Katılımcıların 214’ü erkek, 274'ü kadındır. 6 katılımcı cinsiyetini belirtmemiştir. 140 katılımcı daha önce girişimcilik ile ilgili bir ders aldığını belirtirken, 350 tanesi söz konusu olgu ile ilgili bir ders almadığını belirtmiş, 4 katılımeı ise ilgili soruya herhangi bir cevap vermemiştir. Katılımcılara yönelik demografik bilgiler Tablo 1'de gösterilmektedir.

Tablo 1. Katılımcıların Demografik Özellikleri

\begin{tabular}{|lc|lc|}
\hline Cinsiyet & & Kayıtlı Olduğu Fakülte & \\
\hline Kadın & $274(\%$ 55.24) & İBF & $328(\% 66.40)$ \\
Erkek & $214(\%$ 43.32) & Mühendislik Fak. & $156(\% 31.58)$ \\
Belirtmemiş & $6(\% 1.22)$ & Belirtmemişs & $10(\% 2.03)$ \\
\hline Kayıtlı Olduğu Üniversite & Girişimcilik Dersi Deneyimi & $140(\% 28.34)$ \\
\hline Bitlis Eren & $295(\%$ 59.72) & Var & $350(\% 70.85)$ \\
Dokuz Eylül & $189(\%$ 38.26) & Yok & $4(\% 0.81)$ \\
Belirtmemiş & $10(\%$ 2.03) & Belirtmemiş & \\
\hline
\end{tabular}

\subsection{Analizler ve Bulgular}

Elde edilen veriler üzerinde öncelikli olarak ölçekler için güvenilirlik ve geçerlilik analizleri gerçekleştirilmiştir. Girişimcilik niyeti ölçeğindeki 1 soru, güvenirliliği azalttığı için analiz dışında bırakılmıştır. Kalan maddelerin Cronbach Alpha katsayısı 0,884 olarak belirlenmiştir. Açımlayıcı faktör analizi sonucunda ölçeğin toplam varyansın \% 68,438 ' ini açıkladığı tespit edilmiştir. Girişimcilik niyeti ölçeğinin KMO katsayısı ise 0,825 ve Barlett Test değeri sonucu $\mathrm{p}<, 01$ önem düzeyinde anlamlıdır. Elde edilen sonuç Tablo 2'de gösterilmektedir.

Tablo 2. Girişimcilik Niyeti Bileşenler Matrisi

\section{İFADELER}

Gelecekte bir iş kurma konusunda kararlıyım

Ciddi anlamda kendi işimi kurmayı düşünüyorum

Kendi işimi kurmak ve sürdürmek için her türlü çabayı göstereceğim

Profesyonel olarak hedefim, bir girişimci olmaktır

Bir girişimci olarak her şeyi yapmaya hazırım
FAKTÖR 
Girişimciliğe yönelik destekleyici/güdüleyici etmenlere ilişkin maddelere uygulanan güvenilirlik analizi sonucunda 1 madde güvenilirliği düşürdüğünden analiz dışında bırakılmıştır. Açımlayıcı faktör analizleri sonucunda ise 1 madde daha analiz dışında kalmıştır. Yapılan analiz sonucunda 3 faktörlü bir yapı elde edilmiştir. Bütün maddelerin Cronbach Alpha katsayısı 0,831 olarak tespit edilmiştir. KMO değeri 0,842 olarak tespit edilmiş ve Barlett Test değeri sonucu $\mathrm{p}<, 01$ önem düzeyinde anlamlıdır. İlk boyut \% 21,341, ikinci boyut 18,445 ve son boyut 13,528 olmak üzere toplam varyansı \% 53.315 oranında açıklamaktadır. İlk boyut, bireylerin girişimcilik faaliyeti sonucunda hayallerini ifade ettiği için "özgerçekleştirme" boyutu olarak adlandırılmıştır. Boyut içi güvenilirlik analizi sonucu elde edilen Cronbach Alpha katsayısı 0,792'dir. İkinci boyuttaki maddeler statü ve mevki kazanmak ile ilgili olduğu için "saygınlık" olarak adlandırılmıştır. Saygınlık boyutunun Cronbach Alpha değeri, 0,771 olarak tespit edilmiştir. Son boyut, çalışma hayatındaki işin yapısı ve beklentilerle ilgili olduğu için "işten beklentiler” olarak adlandırılmıştır. Söz konusu boyutun Cronbach Alpha değeri ise 0,654'tür. Girişimciliğe yönelik güdü algılarının açımlayıcı faktör analizi sonuçları Tablo 3 'te görülmektedir.

Tablo 3. Girişimciliğe Yönelik Destekleyici/Güdüleyici Algılar Bileşenler Matrisi

\begin{tabular}{|c|c|c|c|}
\hline \multirow{2}{*}{ IFADELER } & \multicolumn{3}{|c|}{ FAKTÖR } \\
\hline & Öz Gerçekleştirme & Saygınlık & İşten Beklentiler \\
\hline İnsanlar için iş alanı yaratma & ,752 & & \\
\hline Kendine ait bir şey yaratma & 648 & & \\
\hline Özgür olma / Bağımsız hareket etme düşüncesi & ,639 & & \\
\hline Daha fazla serbest zamana sahip olma & ,611 & & \\
\hline Kendi fikirlerimi uygulama isteği & ,608 & & \\
\hline Hayat kalitemi yükseltme &, 576 & & \\
\hline Özgür olmak için gerekli parayı kazanma &, 538 & & \\
\hline İnsanları yönetme & & ,782 & \\
\hline Bir şirketin patronu olma & &, 765 & \\
\hline Zengin olma & & ,739 & \\
\hline Yüksek bir sosyal statü kazanma & & ,661 & \\
\hline Eski işinden mutsuz olma & & & ,788 \\
\hline Adil bir ücret alamama & & & ,729 \\
\hline Doğru işi bulmanın zorluğu & & & ,710 \\
\hline
\end{tabular}

Girişimciliğe yönelik engel algıları ölçeğinin bütün maddeleri ile gerçekleştirilen güvenilirlik ve açımlayıcı faktör analizi sonucunda 2 madde ,050 puandan az miktar ile iki ayrı boyuta yüklendiği için analiz dışında bırakılmıştır. Kalan verilerin Cronbach Alpha değeri 0,904 olarak tespit edilmiştir. Açımlayıcı faktör analizi ile ölçek 4 boyutlu olarak tespit edilmiştir. Ölçeğin KMO değeri 0,905 olarak bulgulanmıştır ve Barlett Test değeri sonucu p<,01 önem düzeyinde anlamlıdır . İlk boyut \% 16,858; ikinci boyut 16,056; üçüncü boyut 13,528 ve son boyut \% 12,677 olmak üzere toplam varyansı \% 59,119' unu açıklamaktadır. İlk boyut girişimcilik ile ilgili bilgi eksikliklerini ifade ettiği için "yetkinlik eksikliği” olarak adlandırılmıştır. İkinci boyut, özellikle girişim kurulduktan sonra karşılaşılan sorunlara yönelik olduğu için "uygulama kaygısı” olarak adlandırılmıştır. Üçüncü boyut, girişimciliğe yönelik çeşitli destek eksikliklerine vurgu yapmasından dolayı "destek eksikliği”"; son boyut ise girişime başlamak konusunda bazı konjüktürel çıkmazları içerdiği için "işe başlama kaygıları" olarak adlandırılmıştır. Boyut içi güvenilirlikler sırasıyla $(0,822),(0,821),(0,756)$ ve $(0,720)$ olarak tespit edilmiştir. Açımlayıcı faktör analizi sonuçları Tablo 4 ’te gösterilmektedir.

Tablo 4. Girişimciliğe Yönelik Engel Algıları Bileşenler Matrisi

\begin{tabular}{|c|c|c|c|c|}
\hline \multirow[b]{2}{*}{ IFADELER } & \multicolumn{4}{|c|}{ FAKTÖR } \\
\hline & $\begin{array}{l}\text { Yetkinlik } \\
\text { Eksikliği }\end{array}$ & $\begin{array}{c}\text { Uygulama } \\
\text { Kaygısı }\end{array}$ & $\begin{array}{c}\text { Destek } \\
\text { Eksikliği }\end{array}$ & $\begin{array}{l}\text { İşe Başlama } \\
\text { Kayglları }\end{array}$ \\
\hline Bilgi eksikliği &, 710 & & & \\
\hline İş ve pazar bilgi eksikliği & 688 & & & \\
\hline Yönetim ve muhasebe konusundaki bilgi eksikliği & 669 & & & \\
\hline Ne tür bir işe başlayacağımı bilememe & ,648 & & & \\
\hline Yeni iş kurmada yardım alamama eksikliği &, 587 & & & \\
\hline Gelirin sabit olmamas1 & &, 825 & & \\
\hline Çalışanlarla yaşanabilecek problemler & & 697 & & \\
\hline Başarısızlık Korkusu & & ,694 & & \\
\hline Çok uzun saatler boyunca çalışma zorunluluğu & &, 625 & & \\
\hline Vergi giderleri (vergiler, yasal harçlar vb.) & &, 547 & & \\
\hline Kendi işini kurma konusunda devlet desteği eksikliği & & &, 763 & \\
\hline Hukuki danışman eksikliği & & & ,733 & \\
\hline Etrafımdaki insanların destek eksikliği & & & ,658 & \\
\hline Girişimcilere yardımcı olacak organizasyon eksikliği & & & ,599 & \\
\hline Genel ekonomik durum & & & & ,779 \\
\hline İşe başlayacak para eksikliği & & & &, 680 \\
\hline Çok fazla risk & & & & ,677 \\
\hline
\end{tabular}


Değişkenler arası ilişkiler korelasyon analizi ile tespit edilmiştir. Destekleyici/Güdüleyici algının alt boyutları olan özgerçekleştirme, saygınlık ve işten beklentiler ile girişimcilik niyeti arasında pozitif ve anlamlı ilişkiler tespit edilmiştir. Engelleyici algının alt boyutları olan olan yetkinlik eksikliği, uygulama kaygıları, kurulum kaygıları ve destek eksikliği boyutları ile girişimcilik niyeti arasında ise negatif ve anlamlı ilişkiler tespit edilmiştir. Korelasyon analizi sonrasında elde edilen korelasyon katsayıları, ortalamalar ve standart sapmalar Tablo 5 'te görülmektedir.

Tablo 5. Değiş̧kenler Arası Korelasyon Kaysayıları, Ortalamalar ve Standart Sapmalar

\begin{tabular}{|c|c|c|c|c|c|c|c|c|c|c|}
\hline Değişkenler & Ort. & St. Sap. & 1 & 2 & 3 & 4 & 5 & 6 & 7 & 8 \\
\hline 1.Girişim. Niyeti & 3,6929 & ,90567 & - & & & & & & & \\
\hline 2. Özgerçekleştirme & 4,1905 & ,57220 &, $338 * *$ & - & & & & & & \\
\hline 3. Saygınlık & 3,8271 & ,84334 &, $341 * *$ &, $518^{* *}$ & - & & & & & \\
\hline 4. İş Beklentileri & 3,9493 & ,74226 &, $230 * *$ &, $362 * *$ &, $224 * *$ & - & & & & \\
\hline 5. Yetkinlik Ek. & 2,0181 & ,70569 &,$- 198 * *$ &,$- 275 * *$ &,$- 248 * *$ &,$- 393 * *$ & - & & & \\
\hline 6. Kurulum Kay. & 2,2100 & ,80508 &,$- 130 * *$ &,$- 216^{* *}$ &,$- 262 * *$ &,$- 394 * *$ &, $491 * *$ & - & & \\
\hline 7. Destek Eksikliği & 2,4206 & ,91501 &,$- 200 * *$ &,$- 234 * *$ &,$- 306 * *$ &,$- 306 * *$ &, $626 * *$ &, $382 * *$ & - & \\
\hline 8. Uygulama Kay. & 2,1684 & ,81728 &,$- 101 *$ &,$- 191 * *$ &,$- 267 * *$ &,$- 347 * *$ &, $616^{* *}$ &, $523 * *$ &, $514 * *$ & - \\
\hline
\end{tabular}

Not: ${ }^{* *} p<0,01,{ }^{*} \mathrm{p}<0,05$

Regresyon analizleri sonucunda destekleyici/güdüleyici ve engelleyici algıların boyutlarının girişimcilik niyeti üzerindeki etkilerini saptamak amacıyla regresyon analizleri gerçekleştirilmiştir. Regresyon analizleri sonucunda girişimciliğe yönelik destekleyici/güdülleyici faktörlere ilişkin algınının alt boyutları olan özgerçekleştirme, saygınlık ve iş beklentileri boyutları, girişimcilik niyetini anlamlı ve pozitif yönde etkilemektedir. Girişimciliğe yönelik engel algıları boyutlarının tamamı da girişimcilik niyetini anlamlı ve negatif yönde etkilemektedir. Bu doğrultuda $\mathrm{H} 1$ ve $\mathrm{H} 2$ kabul edilmiştir. Değişkenler arası regresyon analizlerinin sonuçları Tablo 6'da gösterilmektedir.

Tablo 6. Güdüleyici ve Engelleyici Algılar ile Girişimcilik Niyeti Arasındaki Regresyonlar

\begin{tabular}{|c|c|c|c|c|c|c|c|c|c|c|}
\hline \multirow[b]{2}{*}{ BD } & \multirow[b]{2}{*}{ Model } & \multicolumn{2}{|r|}{ SOK } & \multirow{2}{*}{$\begin{array}{l}\text { SK } \\
\boldsymbol{\beta} \\
\end{array}$} & \multirow[b]{2}{*}{$\mathbf{t}$} & \multirow[b]{2}{*}{$p$} & \multirow[b]{2}{*}{$\mathbf{R}$} & \multirow[b]{2}{*}{$\mathbf{R}^{2}$} & \multirow[b]{2}{*}{$\begin{array}{l}\text { Adjusted } \\
\mathbf{R}^{2}\end{array}$} & \multirow[b]{2}{*}{$\mathbf{F}$} \\
\hline & & B & Standart Hata & & & & & & & \\
\hline GN & $\begin{array}{l}\text { (Sabit) } \\
\text { Özger. }\end{array}$ & $\begin{array}{c}1,449 \\
, 535\end{array}$ & $\begin{array}{l}, 284 \\
, 067\end{array}$ & ,338 & $\begin{array}{l}5,098 \\
7,965\end{array}$ & $\begin{array}{l}, 000 \\
, 000\end{array}$ &, $338^{\mathrm{a}}$ &, 114 &, 113 & 63,439 \\
\hline GN & $\begin{array}{l}\text { (Sabit) } \\
\text { Sayg. }\end{array}$ & $\begin{array}{c}2,292 \\
, 366\end{array}$ & $\begin{array}{l}, 179 \\
, 046\end{array}$ & ,341 & $\begin{array}{c}12,836 \\
8,035\end{array}$ & $\begin{array}{l}, 000 \\
, 000\end{array}$ & ,341a &, 116 & ,114 & 64,558 \\
\hline GN & $\begin{array}{l}\text { (Sabit) } \\
\text { İşBek. }\end{array}$ & $\begin{array}{c}2,585 \\
, 281\end{array}$ & $\begin{array}{l}, 215 \\
, 054 \\
\end{array}$ & ,230 & $\begin{array}{c}12,005 \\
5,235 \\
\end{array}$ & $\begin{array}{l}\text {,000 } \\
, 000 \\
\end{array}$ &, $230^{\mathrm{a}}$ &, 053 &, 051 & 27,401 \\
\hline GN & $\begin{array}{c}\text { (Sabit) } \\
\text { İşBaşKay. }\end{array}$ & $\begin{array}{l}4,028 \\
-, 166\end{array}$ & $\begin{array}{l}, 123 \\
, 057\end{array}$ &,- 130 & $\begin{array}{l}32,813 \\
-2,895\end{array}$ & $\begin{array}{l}, 000 \\
, 004\end{array}$ &, $130^{\mathrm{a}}$ & ,017 &, 015 & 8,380 \\
\hline GN & $\begin{array}{l}\text { (Sabit) } \\
\text { DesEk. }\end{array}$ & $\begin{array}{l}4,192 \\
-, 224\end{array}$ & $\begin{array}{l}, 117 \\
, 050\end{array}$ &,- 200 & $\begin{array}{l}35,889 \\
-4,516\end{array}$ & $\begin{array}{l}, 000 \\
, 000\end{array}$ &, $200^{\mathrm{a}}$ &, 040 & ,038 & 20,397 \\
\hline GN & $\begin{array}{c}\text { (Sabit) } \\
\text { UygKay }\end{array}$ & $\begin{array}{l}3,935 \\
-, 100\end{array}$ & $\begin{array}{l}, 115 \\
, 044\end{array}$ &,- 101 & $\begin{array}{l}34,223 \\
-2,251\end{array}$ & $\begin{array}{l}, 000 \\
, 025\end{array}$ &, $101^{\mathrm{a}}$ &, 010 & ,008 & 5,069 \\
\hline GN & $\begin{array}{l}\text { (Sabit) } \\
\text { YetEk }\end{array}$ & $\begin{array}{r}4,168 \\
-, 219\end{array}$ & $\begin{array}{l}, 114 \\
, 049\end{array}$ &,- 198 & $\begin{array}{l}36,698 \\
-4,472\end{array}$ & $\begin{array}{l}, 000 \\
, 000\end{array}$ &, $198^{\mathrm{a}}$ & ,039 & ,037 & 19,997 \\
\hline
\end{tabular}

Not: BD (Bağımlı Değişken), GN (Girişimcilik Niyeti)

Çalışmanın amacı doğrultusunda destekleyici/güdüleyici ve engelleyici algıların karşılaştırılması için iki değişkenin tek bir puan üzerinden değerlendirilmesi gereklidir. Bu nedenle, analitik hiyerarşi sürecinden faydalanılarak ortaya çıkan boyutlar, girişimcilik üzerine araştırma yapan 8 uzman tarafindan önem derecesine göre 10 puan üzerinden değerlendirilmiştir. Toplam puan içinde her bir boyutun oranı hesaplanarak boyutların ağırlıkları tespit edilmiştir. Analiz sonucunda, girişimciliğe yönelik güdü faktörlerinden özgerçekleştirmenin boyutunun ağırlığı 0,3132; saygınlık boyutunun ağırlığı 0,3297 ve iş beklentileri boyutunun ağırlığı 0,3571 olarak tespit edilmiştir. Bu ağırlıklar ile her bir boyut verileri çarpılarak güdüleyici etmen puanı elde edilmiştir. Girişimciliğe yönelik engel faktörlerinden yetkinlik eksikliği boyutunun ağırlığı 0,2308; kurulum kaygıları boyutunun ağırlığı 0,2591; destek eksikliği boyutunun ağırlığı 0,2713 ve uygulama kaygıları boyutunun ağırlığı ise 0,2389 olarak belirlenmiştir. Ağırlıklarda faydalanarak engelleyici etmen puanı hesaplanmıştır.

Güdüleyici etmen ile engelleyici etmen puanları ile girişimcilik niyeti arasındaki regresyon incelediğinde, güdüleyici etmen puanının, girişimcilik niyetini anlamlı ve pozitif yönde etkilediği; engelleyici etmen puanının ise girişimcilik niyetini anlamlı ve negative yönde etkilediği Tablo 7'de görülmektedir. 
Tablo 7. Güdüleyici ve Engelleyici Etmenlerin Girişimcilik Niyetine Etkisi

\begin{tabular}{|c|c|c|c|c|c|c|c|c|c|c|}
\hline \multirow[b]{2}{*}{ BD } & \multirow[b]{2}{*}{ Model } & \multicolumn{2}{|r|}{ SOK } & \multirow{2}{*}{$\begin{array}{l}\text { SK } \\
\boldsymbol{\beta}\end{array}$} & \multirow[b]{2}{*}{$\mathbf{t}$} & \multirow[b]{2}{*}{$p$} & \multirow[b]{2}{*}{$\mathbf{R}$} & \multirow[b]{2}{*}{$\mathbf{R}^{2}$} & \multirow[b]{2}{*}{ Adjusted $\mathbf{R}^{2}$} & \multirow[b]{2}{*}{$\mathbf{F}$} \\
\hline & & B & Standart Hata & & & & & & & \\
\hline GN & $\begin{array}{c}\text { (Sabit) } \\
\text { Güd. Etmen }\end{array}$ & $\begin{array}{c}1,079 \\
, 656 \\
\end{array}$ & $\begin{array}{l}, 276 \\
, 069 \\
\end{array}$ & ,396 & $\begin{array}{l}3,907 \\
9,552 \\
\end{array}$ & $\begin{array}{l}, 000 \\
, 000 \\
\end{array}$ & $396^{\mathrm{a}}$ & ,157 & 155 & 91,236 \\
\hline GN & $\begin{array}{c}\text { (Sabit) } \\
\text { Eng. Etmen }\end{array}$ & $\begin{array}{l}4,300 \\
-, 274 \\
\end{array}$ & $\begin{array}{l}, 141 \\
, 062 \\
\end{array}$ &,- 197 & $\begin{array}{l}30,443 \\
-4,458 \\
\end{array}$ & $\begin{array}{l}, 000 \\
, 000 \\
\end{array}$ & $197^{a}$ & ,039 & ,037 & 19,874 \\
\hline
\end{tabular}

Güç alanı analizine göre, davranışın ortaya çıkabilmesi için destekleyici/güdüleyici etmen puanın, engelleyici etmen puanından daha yüksek çıkması beklenmektedir. Dolayısı ile güdüleyici etmen ile engelleyici etmen arasındaki fark alınarak yeni bir değişken oluşturulmuş ve bu değişkenin negatif olduğu grup (engelleyici etmen algısının, destekleyici/güdüleyici etmen algılardan daha yüksek olması) "1"; pozitif olduğu grup (destekleyici/güdüleyici etmen algıların engelleyici etmen algısından daha yüksek olması) "2" karekterleriyle kodlanıp örneklem sınıflandırılmıştır. Grup 2 ile grup 1 arasında girişimcilik niyeti algılarına yönelik bir farklılık olup olmadığının analizi için bağımsız örneklem T-testinden faydalanılmış ve iki grubun girişimcilik niyeti algılarının ortalamaları açısından anlamlı bir farklılık olduğu tespit edilmiştir. Güdüleyici algıları engelleyici algılarından daha yüksek olan grubun girişimcilik niyeti algısı, engelleyici algıları güdüleyici algılarından daha yüksek olan grubun girişimcilik niyeti algısından daha yüksektir. Bu doğrultuda H3 kabul edilmiştir. Elde edilen sonuçlar aşağıdaki Tablo 8'de gösterilmektedir.

Tablo 8. Destekleyici/Güdüleyici ve Engelleyici Algı Farkının Oluşturduğu Gruplara Göre Girişimcilik Niyeti Karş1laştırması

\begin{tabular}{|c|c|c|c|c|c|c|c|c|c|c|c|}
\hline \multirow{5}{*}{ GN } & \multicolumn{4}{|c|}{ Grup İstatistikleri } & \multicolumn{7}{|c|}{ Ortalamaların Eşitliği için T-Testi } \\
\hline & \multirow{2}{*}{$\begin{array}{l}\text { Fark } \\
\text { G. }\end{array}$} & \multirow[t]{2}{*}{$\mathbf{N}$} & \multirow[t]{2}{*}{ Ort. } & \multirow{2}{*}{$\begin{array}{l}\text { Sta. } \\
\text { Sap. }\end{array}$} & \multirow[t]{2}{*}{$\mathbf{t}$} & \multirow[t]{2}{*}{ df } & \multirow{2}{*}{$\mathbf{p}$} & \multirow{2}{*}{$\begin{array}{c}\text { Örtalama } \\
\text { Farkı }\end{array}$} & \multirow{2}{*}{$\begin{array}{c}\text { Sta. Sap. } \\
\text { Farkı }\end{array}$} & \multicolumn{2}{|c|}{$\begin{array}{c}\text { \% } 95 \text { Güven } \\
\text { Aralığındaki Fark }\end{array}$} \\
\hline & & & & & & & & & & Alt & Üst \\
\hline & 1 & 193 & 3,5824 & ,93102 & $-2,257$ & 490 & ,024 &,- 18752 & ,08307 &,- 35073 &,- 02431 \\
\hline & 2 & 299 & 3,7699 & ,87878 & $-2,229$ & 392,662 & ,026 &,- 18752 & 08411 &,- 35287 &,- 02216 \\
\hline
\end{tabular}

Araştırmanın merakı dahilinde destekleyici güdüleyici algılar ile engelleyici algılar farkı pozitif yönde artıkça, girişimcilik niyetinin artacağı düşünülmektedir. Bu doğrultuda, söz konusu fark ile girişimcilik niyeti arasındaki regresyon analizleri sonucunda H4 kabul edilmiştir. İlgili tablo aşağıda görülmektedir. Söz konusu farkın, girişimcilik niyetini \%2.1 oranında açıkladığı görülmektedir.

Tablo 9. Güdüleyici Etmen ile Engelleyici Etmen Farkının Girişimcilik Niyetine Etkisi

\begin{tabular}{|c|c|c|c|c|c|c|c|c|c|c|}
\hline \multirow[b]{3}{*}{ BD } & \multirow[b]{3}{*}{ Model } & \multirow{2}{*}{\multicolumn{2}{|c|}{ SOK }} & \multirow{3}{*}{ SK } & \multirow[b]{3}{*}{$\mathrm{t}$} & \multirow[b]{3}{*}{$p$} & \multirow[b]{3}{*}{$\mathbf{R}$} & \multirow[b]{3}{*}{$\mathbf{R}^{2}$} & \multirow[b]{3}{*}{ Adjusted $\mathbf{R}^{2}$} & \multirow[b]{3}{*}{$\mathbf{F}$} \\
\hline & & & & & & & & & & \\
\hline & & B & Standart Hata & & & & & & & \\
\hline GN & $\begin{array}{l}\text { (Sabit) } \\
\text { FARK }\end{array}$ & $\begin{array}{c}3,657 \\
, 214\end{array}$ & $\begin{array}{l}042 \\
, 066\end{array}$ & , 145 & $\begin{array}{c}86,755 \\
3,251\end{array}$ & $\begin{array}{l}\text {,000 } \\
\text {,001 }\end{array}$ &, $145^{\mathrm{a}}$ &, 021 & ,019 & 10,569 \\
\hline
\end{tabular}

\subsection{Tartışma}

Destekleyici/Güdüleyici algılar, Giacomin vd.'nin çalışmasında(2011: 228) karlılık ve sosyal statü peşinde koşma, bağımsızlık arzusu, yaratıcılık, kişisel gelişim ve profesyonel tatminsizlik olarak 5 boyutlu olarak tespit etmektedirler. Pruett vd. (2009: 584) güdüleyici algıları; zenginlik-statü, yaşam stili, bağımsızlık, yaratıcılık ve eşitlik firsatı olarak 5'e ayırmaktadır. Bu çalışmanın özelinde, bağımsızlık arzuları, yaratıcılık ve yaşam stili ile ilgili maddelerin tek bir boyutta toplandığı ve daha çok kendini gerçekleştirmeyi içeren bir yapıya büründüğü gözlenmektedir.

Giacomin vd. (2011: 233) engelleyici algıları; yapısal, mali ve idari destek eksikliği, bilgi ve deneyim eksikliği, ekonomik iklim ve girişimsel yetkinlik eksikliği, özgüven eksikliği ve risk almama olarak 5 boyutlu bulgulamaktadırlar. Pruet vd. (2009: 584) çalışmalarında engel algıları; yapısal destek, bilgi, uygulama riskleri, start-up riskleri, yetkinlik ile sosyal destek şeklinde ayrılmaktadır. Önceki çalışmalardan farklı olarak bu çalışmada, öz yeterlilik ile ilgili maddelerin bilgi eksikliği ile ilgili maddeler ile birlikte faktörü oluşturmaları yetkinlik eksikliği olarak bütünleştirilmiştir. Sosyal desteğin, yapısal destek maddeleri ile birleşmesi de girişimcinin genel bir destek algısını ifade etmesi açısından, elde edilen ölçeğin daha uygun bir yapıya kavuştuğu düşünülmektedir.

Aynı ölçek Giacomin vd. (2011: 233) ile Pruett vd. (2009: 584) kullanılmasına ragmen farklı örneklem gruplarından dolayı farklı bir dağılım göstermektedir. Ülkemizde de ölçek, önceki iki çalışmadan da farklı bir şekilde faktörlere ayrışmaktadır. Destekleyici/Güdüleyici faktörlerin, Maslow’un (1943) ihtiyaç sınıflarına uygun olarak dağıldığı gözlenmektedir. Fizyolojik ve güvenlik ihtiyaçları kapsayan iş beklentileri boyutu, statü ve gücü içeren maddeler ile saygınlık boyutu ve istediği gibi yaşamayı, bağımsız hareket etmeyi ve yaratıcılığı vurgulayan maddeler ile 
özgerçekleştirme boyutu olarak ayrımlandığı gözlenmektedir. Engelleyici algılarda ise önceki çalışmalardaki sonuçlara çok yakın sonuçlar elde edilmiştir.

Çalışmada elde edilen güdüleyici algıların, girişimcilik niyetini olumlu yönde etkilemesi yazın ile tutarlıdır (Pruett vd., 2009; Denanyoh vd., 2015; Lüthje ve Frankie, 2003; Begley vd., 2005; İsmail vd., 2009). Engelleyici algıların, girişimcilik niyetini negative yönde etkilediği sonucu Pruett vd. (2009), Denanyoh vd. (2015), Lüthje ve Frankie (2003), Begley vd. (2005) ve İsmail vd. (2009) çalışmaları ile yine paralellik göstermektedir.

Araştırmanın sonuçları arasında güdüleyici etmen ile engelleyici etmen arasındaki farkın negatif olduğu grubunda girişimcilik niyeti ortalamasının 3,5 puanın üzerinde olduğu görülmektedir. Aslında Lewin'in Alan Kuramı (1997) bağlamında bu puanın 3'ün altında olması beklenebilir. Bu sonucun nedeninin, niyetin davranışın en önemli öncülü olmasına karşın her zaman niyetin davranışa dönüşmemesi olduğu düşünülmektedir. Kolvereid (1996a) çalışmasında öğrencilerin \% 43'ünün kendi işine sahip olmak istediğini belirtirken, sadece \% 7'sinin girişimci olabileceğini ifade etmektedir.

\section{Sonuç ve Öneriler}

$\mathrm{Bu}$ araştırmada, Güç Alanı Teorisi kapsamında girişimcilik niyetinin öncülleri olarak değerlendirilen girişimciliğe yönelik destekleyici/güdüleyici algılar ile engelleyici algıların etkileşiminin girişimcilik niyetine etkileri değerlendirmektedir. Nitekim araştırma sonuçlarına göre güç alanı teorisi bağlamında oluşturulan tüm hipotezler kabul edilmiştir. Bu sonuçlara göre birey karar ve davranışlarına önemli düzeyde etkileyen niyet destekleyici ya da engelleyici çevresel etmenlerin gücüne göre değişiklik gösterecektir. $\mathrm{Bu}$ bağlamda güç alanı kuramı çevresel destekleyici/güdüleyici ve engelleyici faktörlerin bireyin niyeti üzerindeki etkilerini bir arada değerlendiren bir yapıya sahiptir. Buradan hareketle destekleyici/güdüleyici güçler ve engelleyici güçler arasındaki orantısızlık kişi karar ve davranışını bu iki farklı gücün pozitif farkı yününde olumlu yada olumsuz olarak etkileyeceği sonucuna ulaşılabilir. Dolayısıyla girişimcilik niyetine etki eden faktörlere yönelik olarak gerçekleştirilen bilimsel araştırmaların her iki bağlamıda aynı anda değerlendirmesi ve gücünü hesaba katması gerekmektedir. Bununla birlikte her ne kadar niyet davranışın yordayıcısı olsa da girişimciliğe yönelik niyetin her zaman girişimcilik davranışını ortaya çıkarmayacağıda bir kısıt olarak belirtilmelidir.

Çalışma, güç alanı analizini girişimcilik niyeti olgusu ile değerlendirmektedir. Fakat Alan Kuramı, bireyin çevrelediği alanın bireyin davranışlarını nasıl etkilediğine dair bir bakış açısı sunmaktadır. Bundan sonraki araştırmalarda, girişimcilik niyetini ve girişimsel faaliyeti birlikte değerlendirecek bir çalışmanın yapıılmasının alana katk1 sağlayacağı düşünülmektedir. Bunun yanı sıra özellikle girişimsel eğitimin yüksek öğretim kurumlarında önemli bir yere sahip olması ve bu eğitimin, geleceğin girişimcilerinin dönüşümünün en etkili yolu olması (Ismail vd., 2009: 55) girişimcilik dersinin içeriğini de önemli hale getirmektedir. Çünkü, Krueger ve Brazeal (1994: 93) belirttiği gibi niyetin öğrenme ile geliştirilebilir olması, eğitim ile bireylerin girişimcilik faaliyetlerini artırmak için önemli bir firsat oluşturmaktadır. Girişimcilik ders içerikleri, girişimciliğin özendirilmesi ve artırılması için destekleyici/güdüleyici faktörlerin geliştirilmesine ağırlık verirken, engelleyici faktörleri azaltmaya yönelik kısımlar görece daha kısır kalmaktadır. Araştırmanın sonuçları, özellikle girişimcilik niyeti ve girişimsel faaliyetlerde önemli bir etkisi olan girişimcilik eğitiminde (Linan vd., 2011:196) engelleyici algıların azaltılmasına yönelik bilgilendirmenin en az destekleyici/güdüleyici algıların artırılmasına yönelik bilgilendirme kadar önemli olduğunu göstermektedir. Bu anlamda söz konusu düzenlemelerin girişimcilik faaliyetlerini artırma açısından destek sağlayacağı düşünülmektedir.

Yazarların bilgisi dahilinde güç alanı kuramını eksenine alan benzer bir değerlendirmeye alan yazınında rastlanmamıştır. Bu bakımdan bu konu üzerinde araştırma yapmak isteyen araştırmacılara benzer araştırmaların farklı bağlam ve örneklemlerle yapılması da önerilmektedir. Araştırma sonuçları bağlamında ayrıca bilim insanlarına, politika yapıcılara ve eğitmenlere, bireylerin girişimci davranışlarının önemli bir öncülü olarak değerlendirilen girişimcilik niyetinin geliştirilmesinde sadece girişimciliğe yönelik güdüleyici algılarının artırılması faaliyetleri değil, yüksek engelleyici algılarının düşürülmesine yönelik faaliyetleri de dikkate almaları önerilmektedir. 
Uçar, Z., Sezgin, O., B. / Journal of Yasar University, 2019, 14 (Special Issue), 46-57

\section{KAYNAKÇA}

Ajzen, I. (1991) 'The Theory of Planned Behavior' Organizational Behavior and Human Decision Processes, 50(2), $179-211$.

Akpınar, T., \& Küçükgöksel, N. Ç. (2015) 'Meslek Yüksekokulu Öğrencilerinin Girişimcilik Algısı ve Girişimciliği Engelleyen Sebepler’ Balkan ve Yakın Doğu Sosyal Bilimler Dergisi, 1(1), 13-19.

Amit, R., MacCrimmon, K. R., Zietsma, C., \& Oesch, J. M. (2001) 'Does Money Matter? Wealth Attainment as The Motive for İnitiating Growth-Oriented Technology Ventures' Journal of Business Venturing, 16(2), 119-143.

Apospori, E., Papalexandris, N., \& Galanaki, E. (2005) 'Entrepreneurial and Professional CEOs: Differences in motive and responsibility profile', Leadership and Organization Development Journal, 26(2), 141-162.

Bae, T. J., Qian, S., Miao, C., \& Fiet, J. O. (2014) 'The Relationship Between Entrepreneurship Education and Entrepreneurial Intentions: A Meta-Analytic Review' Entrepreneurship Theory and Practice, 38(2), $217-254$.

Baker, T. \& Pollock, T. G. (2007) 'Making The Marriage Work: The Benefits of Strategy's Takeover of entrepreneurship for Strategic Organization' Strategic Organization, 5(3),297-312.

Begley, T. M., Tan, W. L., \& Schoch, H. (2005) 'Politico-Economic Factors Associated with İnterest in Starting A Business: A Multi-Country Study’ Entrepreneurship Theory and Practice, 29(1), 35-55.

Berthaume, A. L., Romoser, M. R., Collura, J., \& Ni, D. (2014) 'Towards A Social Psychology-Based Microscopic Model of Driver Behavior and Decision-Making: Modifying Lewin's Field Theory' The 3rd International Workshop on Agent-based Mobility, Traffic and Transportation Models, Methodologies and Applications (ABMTRANS), Procedia Computer Science 32 ( 2014 ), 816 - 821.

Bird, B. (1988) 'Implementing Entrepreneurial İdeas: The Case for İtention' Academy of Management Review, 13(3), 442-453.Birley, S., \& Westhead, P. (1994) A Taxonomy of Business Start-Up Reasons and Their Impact on Firm Growth and Size. Journal of Business Venturing, 9, 7-31.

Buttner, E. H., \& Moore, D. P. (1997) 'Women's organizational exodus to entrepreneurship: Self-reported motivations and correlates with success' Journal of Small Business Management, 35(1), 34-46.

Bygrave, WD. (1993) 'Theory Building in The Entrepreneur Paradigm' Journal of Business Venturing, 8(3):255-280.

Carayannis, E. G., Evans, D., \& Hanson, M. (2003) 'A Cross-Cultural Learning Strategy for Entrepreneurship Education: Outline of Key Concepts and Lessons Learned from A Comparative Study of Entrepreneurship Students in France and The US' Technovation, 23(9), 757-771.

Carter, N. M., Gartner, W. B., Shaver, K. G., \& Gatewood, E. J. (2003) 'The Career Reasons of Nascent Entrepreneurs' Journal of Business Venturing, 18, 13-39.

Cartwright, D. (1951) ' Field Theory in Social Science and Selected Theoretical Papers-Kurt Lewin'. Washington, D.C.: American Psychological Association, 1997. Originally published by Harper \& Row.

Casper, E.S. (2007) 'The Theory of Planned Behavior Applied to Continuing Education for Mental Health Professionals' Journal of Psychiatric Services. 58(10): 1324-1329.

Cassar, G. (2007) 'Money, Money, Money? A Longitudinal İnvestigation of Entrepreneur Career Reasons, Growth Preferences, and Achieved Growth' Entrepreneurship \& Regional Development 19, 89-107.

Choo, S., \& Wong, M. (2006) 'Entrepreneurial Intention: Triggers and Barriers to New Venture Creations in Singapore' Singapore management review, 28(2), 47-64.

Chye Koh, H. (1996) 'Testing Hypotheses of Entrepreneurial Characteristics: A Study of Hong Kong MBA Students' Journal of managerial Psychology, 11(3), 12-25.

DeMartino, R., \& Barbato, R. (2003) 'Differences Between Women and Men MBA Entrepreneurs: Exploring Family Flexibility and Wealth Creation as Career Motivators' Journal of Business Venturing, 18, 815-832.

Denanyoh, R., Adjei, K., \& Nyemekye, G. E. (2015) 'Factors That Impact on Entrepreneurial İntention of Tertiary Students in Ghana' International Journal of Business and Social Research, 5(3), 19-29.

Douglas, E. J., \& Shepherd, D. A. (2002) 'Self-Employment as A Career Choice: Attitudes, Entrepreneurial Intentions, and Utility Maximization’ Entrepreneurship Theory and Practice, 26(3), 81-90.

Edelman, L. F., Brush, C. G., Manolova, T. S., \& Greene, P. G. (2010) 'Start-Up Motivations and Growth Intentions of Minority Nascent Entrepreneurs’ Journal of Small Business Management, 48(2), 174-196.

Engle, R. L., Dimitriadi, N., Gavidia, J. V., Schlaegel, C., Delanoe, S., Alvarado, I., ... \& Wolff, B. (2010) 'Entrepreneurial Intent: A Twelve-Country Evaluation of Ajzen's Model of Planned Behavior' International Journal of Entrepreneurial Behavior \& Research, 16(1), 35-57.

Erten, S. (2002) 'Planlanmış Davranış Teorisi ile Uygulamalı Öğretim Metodu' Hacettepe Üniversitesi Edebiyat Fakültesi Dergisi, 19(2): 217-233.

Fatoki, O. O., \& Chindoga, L. (2012) 'Triggers and Barriers to Latent Entrepreneurship in High Schools in South Africa' Journal of Social Sciences, 31(3), 307-318.

Feldman, D. C., \& Bolino, M. C. (2000) 'Career Patterns of the Setf-Etnployed: Career Motivations and Career Outcomes' Journal of Small Business Management, 38(3), 53-68.

Fayolle, A., \& Linan, F. (2014) 'The Future of Research on Entrepreneurial İntentions. Journal of Business Research, 67(5), 663-666.

Franklin, R. J. (2013). 'Motives, Self-Regulation, and A Re-Conceptualization of Entrepreneurial Success' (Doctoral dissertation, Oklahoma State University). 
Uçar, Z., Sezgin, O., B. / Journal of Yasar University, 2019, 14 (Special Issue), 46-57

Gatewood, E. J., Shaver, K. G., \& Gartner, W. B. (1995) 'A Longitudinal Study of Cognitive Factors İnfluencing StartUp Behaviors and Success at Venture Creation’ Journal of Business Venturing, 10, 371-391.

Giacomin, O., Janssen, F., Pruett, M., Shinnar, R. S., Llopis, F., \& Toney, B. (2011) 'Entrepreneurial intentions, motivations and barriers: Differences among American, Asian and European students' International Entrepreneurship and Management Journal, 7(2), 219-238.

Gözek, S., \& Akbay, C. (2012) 'Girişimci Adaylarının Girişimcilik Eğilimleri ve Sorunları’ Kahramanmaraş Sütçü Imam Üniversitesi Sosyal Bilimler Dergisi, 9(2), 45-60.

Hatala, J. P. (2005) 'Identifying Barriers to Self- Employment: The Development and Validation of The Barriers to Entrepreneurship Success Tool' Performance Improvement Quarterly, 18(4), 50-70.

Hayter, C. S. (2011) 'In Search of The Profit-Maximizing Actor: Motivations and Definitions of Success from Nascent Academic Entrepreneurs' Journal of Technology Transfer, 36, 340-352.

Hisrich, R.D. \& Brush, C. (1986) 'Characteristics of The Minority Entrepreneur' Journal of Small Business Management, 24, 1-8.

Hughes, K.D. (2003) 'Pushed or pulled? Women's Entry İnto Self-Employment and Small Business Ownership' Gender, Work and Organization, 10(4), 433-454.

Ismail, M., Khalid, S. A., Othman, M., Jusoff, H. K., Rahman, N. A., Kassim, K. M., \& Zain, R. S. (2009) 'Entrepreneurial Intention Among Malaysian Undergraduates' International Journal of Business and Management, 4(10), 54-60.

Katz, J., \& Gartner, W. B. (1988) 'Properties of Emerging Organizations’ Academy of Management Review, 13(3), 429-441.

Kaufmann, P. J., Welsh, D. H., \& Bushmarin, N. V. (1995) 'Locus of Control and Entrepreneurship in the Russian Republic' Entrepreneurship Theory and Practice, 20(1), 43-56.

Kirchner, M. (2000) 'Gestalt Therapy Theory: An Overwiew' Journal of Gestalt Therapy 4, (3).

Kirkwood, J. (2009) 'Motivational Factors in A Push-Pull Theory Of Entrepreneurship' Gender in Management: An International Journal, 24(5), 346-364.

Kolvereid, L. (1996a). Organizational Employment Versus Self-Employment: Reasons for Career Choice İntentions. Entrepreneurship Theory and Practice, 20(3), 23-31.

Kolvereid, L. (1996b) 'Prediction of Employment Status Choice İntentions' Entrepreneurship Theory and Practice, 21(1), 47-58.

Korkmaz, O. (2012) 'Üniversite Öğrencilerinin Girişimcilik Eğilimlerini Belirlemeye Yönelik Bir Araştirma: Bülent Ecevit Üniversitesi Örneği’ Afyon Kocatepe Üniversitesi Íktisadi ve İdari Bilimler Fakültesi Dergisi, 14(2), 209-226.

Krueger Jr, N. F., \& Brazeal, D. V. (1994) ‘Entrepreneurial Potential and Potential Entrepreneurs’ Entrepreneurship Theory and Practice, 18(3), 91-104.

Krueger Jr, N. F., Reilly, M. D., \& Carsrud, A. L. (2000) 'Competing Models of Entrepreneurial Intentions' Journal of Business Venturing, 15(5-6), 411-432.

Krueger, N. F., \& Carsrud, A. L. (1993) 'Entrepreneurial Intentions: Applying The Theory of Planned Behaviour' Entrepreneurship \& Regional Development, 5(4), 315-330.

Kunday, Ö. (2014) 'Girişimci Olma Nedenleri İle Karşıllaşıllan Engeller Arasındaki İlişki Üzerine Bir Araştırma' Girişimcilik ve Kalkınma Dergisi, 9 (2), 314-329.

Kuratko, D.F., Hornsby, J.S. \& Naffziger, D.W. (1997), 'An Examination of Owners' Goals in Sustaining Entrepreneurship', Journal of Small Business Management, 35(1), 24-33.

Lee, S. M., \& Peterson, S. J. (2000) 'Culture, Entrepreneurial Orientation, and Global Competitiveness' Journal of World Business, 35(4), 401-416.

Lee, S. M., Chang, D., \& Lim, S. B. (2005) 'Impact of Entrepreneurship Education: A Comparative Study of The US and Korea' The International Entrepreneurship and Management Journal, 1(1), 27-43.

Lewin, K. (1951) 'Field Theory in Social Science: Selected Theoretical Papers (Edited by Dorwin Cartwright.)' Oxford, England: Harpers.

Lewin, K. (1997) 'Defining the 'Field at a Given Time.' Psychological Review; 1943; 50: 292-310. Republished in Resolving Social Conflicts \& Field Theory in Social Science, Washington, D.C.: American Psychological Association, 1997.

Li, W. (2007) 'Ethnic Entrepreneurship: Studying Chinese and Indian Students in the United States. Journal of Developmental Entrepreneurship' 12(04), 449-466.

Linan, F. \& Chen, Y. W. (2009) 'Development and Cross- Cultural Application of A Specific Instrument to Measure Entrepreneurial Intentions' Entrepreneurship Theory and Practice, 3(33), 593-617.

Linan, F., Rodríguez-Cohard, J. C., \& Rueda-Cantuche, J. M. (2011) 'Factors Affecting Entrepreneurial Intention Levels: A Role For Education' International Entrepreneurship and Management Journal, 7(2), 195-218.

Lortie, J., \& Castogiovanni, G. (2015) 'The theory of Planned Behavior in Entrepreneurship Research: What We Know and Future Directions' International Entrepreneurship and Management Journal, 11(4), 935-957.

Lüthje, C., \& Franke, N. (2003) 'The 'Making' of An Entrepreneur: Testing A Model of Entrepreneurial İntent Among Engineering Students at MIT’ $R \& D$ Management, 33(2), 135-147. 
Marangoz, M., \& Aydin, A. E. (2018) 'Girişimcilik Motivasyonları ve Engellerine İlişkin Algıların Girişimcilik Niyetine Etkisi: Üniversite Öğrencilerine Yönelik Bir Araştırma’ Girişimcilik ve Kalkınma Dergisi, 13(1), 6978.

Maslow, A. H. (1943) ‘A Theory of Human Motivation’ Psychological Review, 50(4), 370-396.

Moon, Zola. K., Farmer, Farmer. L., Miller, Wayne. P., \& Abreo, Christina. (2014) 'Identification and Attenuation of Barriers to Entrepreneurship: Targeting New Destination Latino Migrants'Economic Development Quarterly, 28(1), 61-72.

Obschonka, M., Silbereisen, R. K., \& Schmitt-Rodermund, E. (2010) 'Entrepreneurial Intention As Developmental Outcome' Journal of Vocational Behavior, 77(1), 63-72.

Öner, U., \& Gümüş, A. E. (2000) Kurt Lewin ve Alan Kuramı1 Lewin'in Çocuk Psikolojisi’ Ankara Üniversitesi Eğitim Bilimleri Fakültesi Dergisi, 33(1), 9-27.

Pruett, M., Shinnar, R., Toney, B., Llopis, F. \& Fox, J. (2009) 'Explaining Entrepreneurial Intentions of University Students: A Cross-Cultural Study’ International Journal of Entrepreneurial Behavior \& Research, 15(6), 571594.

Schultz, D. P., \& Schultz, S. E. (2001) 'Modern Psikoloji Tarihi' (çev. Yasemin Aslay). İstanbul: Kaknüs Yayınları.

Singh Sandhu, M., Fahmi Sidique, S., \& Riaz, S. (2011) 'Entrepreneurship Barriers and Entrepreneurial Inclination Among Malaysian Postgraduate Students. International Journal of Entrepreneurial Behavior \& Research, 17(4), 428-449.

Sundberg, N. D., Winebarger, A. A., \& Taplin, J. R. (2002) 'Clinical psychology: Evolving theory, practice, and research' Prentice Hall/Pearson Education.

Tkachev, A., \& Kolvereid, L. (1999) ‘Self-Employment Intentions among Russian students’ Entrepreneurship \& Regional Development, 11(3), 269-280.

Van Gelderen, M., \& Jansen, P. (2006) 'Autonomy as A Start-Up Motive' Journal of Small Business and Enterprise Development, 13(1), 23-32.

Walters, D., \& Buchanan, J. (2001) 'The New Economy, New Opportunities And New Structures' Management Decision, 39(10), 818-834.

Wennekers, S. \& Thurik, R. (1999) 'Linking Entrepreneurship and Economic Growth' Small Business Economics, 13(1), 27-56.

Wİckham, Philip A. (2006) 'Strategic entrepreneurship' Financial Times Prentice Hall, UK.

Wilson, F., Marlino, D., \& Kickul, J. (2004) 'Our Entrepreneurial Future: Examining the Diverse Attitudes and Motivations of Teens Across Gender and Ethnic Identity’ Journal of Developmental Entrepreneurship, 9, 177 197.

Zampetakis, L. A., Gotsi, M., Andriopoulos, C., \& Moustakis, V. (2011) 'Creativity and Entrepreneurial Intention in Young People: Empirical Insights from Business School Students’ The International Journal of Entrepreneurship and Innovation, 12(3), 189-199.

Zimmerer, T. W., \& Scarboroug, N. M. (2005) 'Essentials of Entrepreneurship and Small Business Management' Prentice-Hall. 